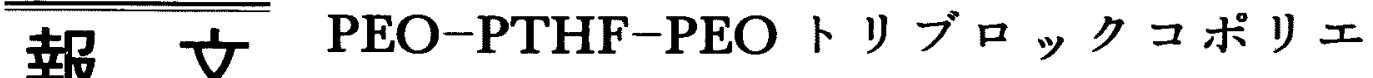 ーテルをベースとするセグメント化ポリウ レタンの抗血栓性と力学的性質
}

(昭和63年 9 月 2 日 受理)

\author{
池田 裕子*1.竹迫 样一*1.粷谷 信三*1 \\ 山下 晋三*1.山下 岩男*2
}

\begin{abstract}
要 旨 新規生体適合性エラストマーを得るために，ポリ(オキシェチレン)ーポリ(オキンテトラィチレ ン)ーポリ(オキシェチレン)トリブロックポリエーテルをでースとするセクメント化ボリウレタン(SEU)を 合成した. Lee-White 法凝血試験及び血小板粘着試験による in vitro 抗血栓性試験の結果, SEUはポり(オ キンテトラメチレン)をべースとするセグント化ボリウレタン(SPU)よりも優れた抗血栓性を示した。

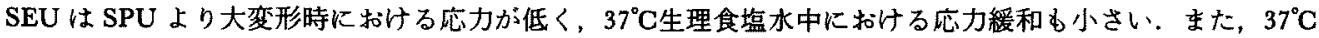
生理食塩水中での 6 か月間にわたる加水分解試験の結果, SEUは良好な耐加水分解性を示すことが明らか となった.SEUの優れた抗血栓性と力学的性質はポリ（オキシェチレン）単位の導入による親水性の増加と ミクロ相分離構造の発達が影響していると考えられる。
\end{abstract}

\section{1. 緒}

言

近年, 種々の機能性を備卉た高分子材料の研究 が盛んであり，特に生体適合性を有する高分子材 料は生体と接触して利用されるため, 高度な機能 に加竞，更に適切な高強度及び低弾性率など，数 々の力学的性質が要求されている(1)2)。例えば人 工心缄では，優れた抗血栓性はもちろんのこと， 1 日に10万回に及ぶ拍動の繰り返しに耐えるだけ の力学的性質と耐疲労性が要求される22. ポリ (オキシテトラメチレン)(PTHF)と 4,4'-ジフェ ニルメタンジインシアナート(MDI) とエチレン シアミン(ED)より合成されたセグメント化ポリ ウレタンウレアは良好な抗血栓性 ${ }^{3) ~-5) ~}$ 之優れた力 学的性質ならびに加水分解安定性 ${ }^{6), 7)}$ を有する高 分子材料であり，Biomer ${ }^{\circledR}$ とし人工心藏の素材 に用いられているす。 。またジアミンの代わりに ジオールで鎖延長反応を行ったセグィント化ポリ ウレタンには，PTHF，MDI及びブタンジオー ルより合成された Pellethane ${ }^{\circledR}$, PTHF, 水素化 MDI 及びブタンジオールより得られた Tecoflex ${ }^{\oplus}$

*1 京都工芸瀻維大学工芸学部工業化学教室 $(\boldsymbol{\Gamma} 606$ 京都市左京区松ヶ崎)

*2 大阪工業技術試験所（宁563 大阪府池田市緑ヶ丘）
などがあり，医用素材として商品化されている99. ポリウレタンの抗血栓性向上のだめに，その他，

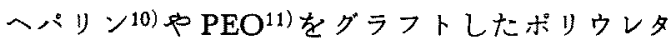
ンの研究もある。すでに我々は分子量1830の PTHF の両末端にPEOを有するトリブロックコ ポリエーテル(HT-ETE, Fig. 1)とMDI及び

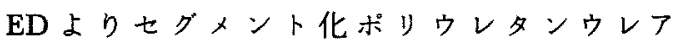
（SEUU）を合成し，その抗血栓性と力学的性質を 評価した ${ }^{12), 13)}$ 。その結果，SEUUは Biomer ${ }^{\circledR}$ に 匹敵する力学的特性と優秀な抗血栓性を兼汉備兄 ていることを報告した。

本研究では，HT-ETEとMDI とェチレング リコール(EG)よりセグメント化ポリウレタン （SEU，Fig. 1)を合成し，抗血栓性と力学的性質 を調查して，医用高分子材料としての評価を行な った。既報のSEUUの結果と比較してウレタン とウレタンウレフとの差についても若干の考察を 行った。

\section{2. 実験}

2.1 セグメント化ポリウレタンの合成 ${ }^{12)}$

セグメント化ポリウレタンはプレポリマー法に より合成した，窒素下， $\mathrm{N}, \mathrm{N}^{\prime}$ ージメチルアセ卜 アミド(DMAc)中, 1,8-ジアザビシクロ [5. 4. 
$\left.\mathrm{HO}+\mathrm{CH}_{2} \mathrm{CH}_{2} \mathrm{O}\right)_{n}+\mathrm{CH}_{2} \mathrm{CH}_{2} \mathrm{CH}_{2} \mathrm{CH}_{2} \mathrm{O}+\mathrm{CH}_{2} \mathrm{CH}_{2} \mathrm{O}{ }_{n} \mathrm{H}$

HT-ETE

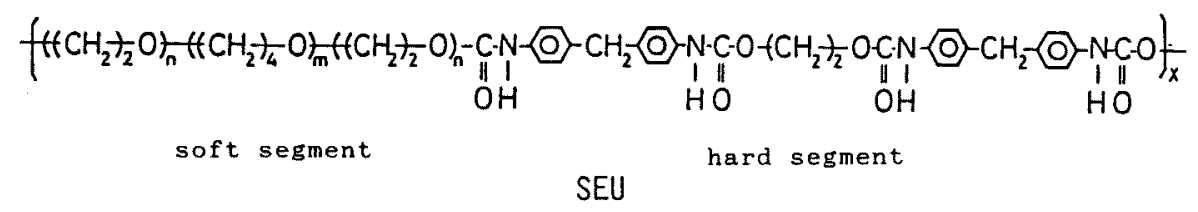

Fig. 1 Chemical structures of HT-ETE and SEU.

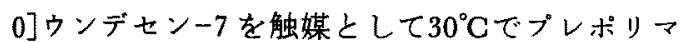
一とMDIを1.5時間反応させた後, 反応溶液を DMAc で希釈後 EG/DMAc 溶液を滴下して鎖延 長反応を行った。 反応を完結させるため, 反応液 を 30 分間で $50^{\circ} \mathrm{C}$ で昇温させた。 大量の水に沈 殿させてポリマーを回収後洗浄し, 減圧下 $40^{\circ} \mathrm{C}$ で乾燥した。仕込みモル比はプレポリマー/ $\mathrm{MDI} / \mathrm{EG}=1 / 2 / 1$ である. 得られたポリウレタン はアセトンにて48時間ソックスレー抽出を行い精 製した。

\section{2 セグメント化ポリウレタンの分子量測定} ポリスチレン換算数平均分子量は侏 トーソ一製 高速液体クロマトグラフ HLC-802UR (GPC)を 用いて測定した，溶出液はTHFを用い，流速 1 $\mathrm{m} l / \mathrm{min}$ ，カラム温度 $40^{\circ} \mathrm{C} て ゙$ 測定した。

2.3 セグメント化ポリウレタンフィルムの作 製

物性試験に供したフィルムはセグメント化ポリ ウレタンの $4 \mathrm{wt} \%$ 又は $10 \mathrm{wt} \% \mathrm{DMAc}$ 溶液からキ ヤスト法で作製した。溶媒の蒸発は減圧下 $(5$ $\mathrm{mmHg}$ 以下), 室温から50 $\mathrm{C}$ む゙加熱して行った。

2.4 セグメント化ポリウレタンのIR及び DSC 測定

IR 測定はキャスト法により作製したフィルム 状試料を用いて日立侏製 HITACHI 215 Grating Infrared Spectrophotometerにより行った. DSC 測定は理学電機侏製 DSC-8230型により窒素気流 下, 昇温速度 $10^{\circ} \mathrm{C} / \mathrm{min}$ で行った.

2.5 セグメント化ポリウレタンの抗血栓性の 評価

抗血栓性の評価は Lee-White 法凝血試験と血 小板粘着試験により行った。

2.5.1 Lee-White 法频血試験12)，14) ポリマー を均一にコーティングした直径 $1 \mathrm{~cm}$, 深さ10 $\mathrm{cm}$ の試験管に採血直後のヒトの全血 $1 \mathrm{ml}$ を入れ, 2 本 1 組で $37^{\circ} \mathrm{C} に$ 保ち， 5 分間静置の後， 1 分ご とに45度に傾けて凝固時間を測定した。ポリマー をコーティングしていないガラス試験管内での凝 血時間を 1 とする相対值(凝血時間指標：CTI)に より抗血栓性を評価した。

2.5 .2 血小板粘着試験 ${ }^{12)} 37^{\circ} \mathrm{C}$ 雾囲気下, キ ヤスト法で作製したフィルムの空気面に採血直後 のヒトの全血 1 滴を 1.5 分間接触させた後, 等張 リン酸緩衝溶液で洗浄し， $0{ }^{\circ} \mathrm{C}$ 水浴中， $2.5 \%$ の グルタルアルデヒド溶液で3時間固定化を行っ た. 試料を徐々にメタノールで置換し, 脱水後, 液化二酸化炭素の臨界点を利用した臨界点乾燥法 により乾燥して，Au-Pt 合金による蒸着後, Hitachi-Akashi Mini SEMにより血小板観察を 行った.

\section{6 力学的性犋の評価}

力学的性質は引張試験及び応力緩和試験により 評価した。

2.6.1 引張試験 引張特性は新興通信工業(救) 製 TOM200D 型引張試験機を用いて評価した。 キャスト法により作製した200〜 $500 \mu \mathrm{m}$ ，幅 5 $\mathrm{mm}$, 長さ 4 $5 \mathrm{~cm}$ のたんざく状の乾燥フィルム と $37^{\circ} \mathrm{C}$ 生理食塩水中に 2 週間浸せきさせた後の 含水フィルムを試料として用いた。測定条件は室 温空気中, チャック間隔 $2 \mathrm{~cm}$, 引張速度 $50 \mathrm{~mm} /$ $\min$ である. 含水フィルムの含水率は式(1)により 求めた。

Water content (wt \%)

$$
=\frac{\text { (wt. of wet film })-(\text { wt. of dry film })}{\text { (wt. of dry film) }} \times 100
$$

2.6.2 応力綏和試験 日合商事(㑣製小型伸長 応力緩和装置を用いて, $37^{\circ} \mathrm{C}$ 生理食塩水中で行 った ${ }^{13)}$. キャスト法で作製した，厚さ $90 \sim 110$ 
PEO-PTHF-PEOトリブロックコポリエーテルをべースとする

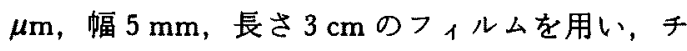
+ック間隔 $18.0 \mathrm{~mm}$, 引張速度 $300 \mathrm{~mm} / \mathrm{min}$ で測 定した。伸長度は生理的な長さに相当する值，す なわち初期長さの $30 \%{ }^{15)}$ とした。

\section{7 セグメント化ポリウレタンの耐加水分解} 性の評価

加水分解試験は $37^{\circ} \mathrm{C}$ 生理食塩水中に 6 か月間 浸せきした後の含水フィルムを試料として2.6.1 に準じる万法により行った。

\section{3. 結果と考察}

\section{1 セグメント化ポリウレタンの合成}

Table 1 にセグメント化ポリウレタンの合成条 件を，Table 2 に GPC 測定の結果を示す．合成 は均一溶液状態で進行した。いずれの反応におい ても反応点 (办酸基)濃度を一定にして合成を行っ たが，ポリスチレン換算数平均分子量はブレポリ マーの分子量の增大に伴い减少し，ブレポリマー により反応性が異なることが明らかとなった。

\section{2 セグメント化ポリウレタンのIR及び} DSC 分析

Fig. 2 にSEUのIR スペクトルを示す. 3350 $\mathrm{cm}^{-1}$ K水素結合した $\mathrm{NH}$ 伸樎振動(a)，1750 $\mathrm{cm}^{-1}$ に水素結合していないウレタン基の CO 伸縮振 動(c)，1720 $\mathrm{cm}^{-1}$ に水素結合したウレタン基の $\mathrm{CO}$ 伸縮振動(d), $820 \mathrm{~cm}^{-1}$ と $780 \mathrm{~cm}^{-1}$ にベンゼン 環 1,4 二置換 $\mathrm{CH}$ 変角振動を示すピーク(f)が現 れ，ハードセグメントの存在が確認できた。また ソフトセグメントは, $1100 \mathrm{~cm}^{-1}$ の脂肪族エーテ
Table 2 Results of GPC Measurements for Segmented Polyurethane

\begin{tabular}{cccc}
\hline Sample code & Mw & Mn & Mw/Mn \\
\hline SPU-2 & 204000 & 28000 & 7.3 \\
SEU-3 & 104000 & 21100 & 4.9 \\
SEU-6 & 49000 & 12400 & 4.0 \\
\hline
\end{tabular}

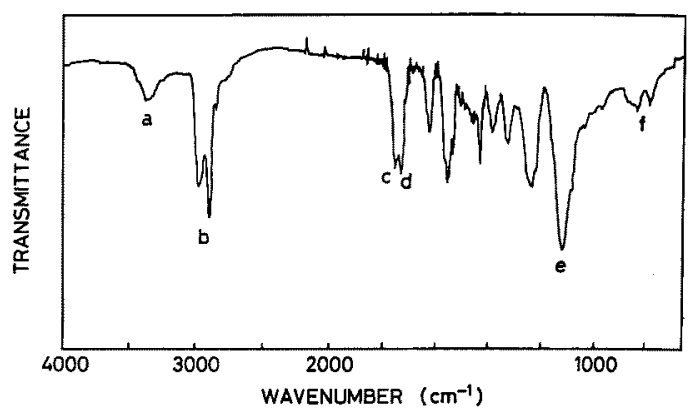

Fig. 2 IR spectrum of SEU-3.

ル伸縮振動(e)及び $2940 \mathrm{~cm}^{-1}, 2850 \mathrm{~cm}^{-1}$ の $\mathrm{CH}_{2}$ 伸樎振動(b)のピークにより確認した。

Table 3 にキャスト法で作製したフィルムの DSC 測定結果を示す. SPU-2 と SEU-3ではy フトセグメントのガラス転移点とハードセグメン トの融点を示すビークが現れ，ミクロ相分離構造 を呈していることが明らかとなった。しかし， SPU-2 の相転移温度はSEU-3より，ガラス転 移温度は高く，融点は低い。これはSEU-3のミ クロ相分離が SPU-2 上り良好に進行しているこ

Table 1 Synthesis ${ }^{\mathrm{a})}$ of Segmented Polyurethane

\begin{tabular}{|c|c|c|c|c|c|c|c|c|c|c|}
\hline \multirow[b]{2}{*}{ Sample code } & \multicolumn{2}{|c|}{ Prepolymer } & \multicolumn{4}{|c|}{ Reaction of the prepolymer and MDI } & \multicolumn{3}{|c|}{ Chain-extention reaction } & \multirow[b]{2}{*}{$\begin{array}{l}\text { Yield } \\
(\%)\end{array}$} \\
\hline & $\mathbf{M}_{\mathbf{n}}^{\mathrm{b})}$ & $\begin{array}{l}\mathrm{EO} \text { content } \mathrm{t}^{\mathrm{c})} \\
(\mathrm{mol} \%)\end{array}$ & $\frac{[\mathrm{DBU}]^{\mathrm{d})}}{\begin{array}{c}{[\mathrm{OH}]} \\
(\%)\end{array}}$ & $\begin{array}{c}\text { Concentration } \\
\text { of the solution } \\
(\%)\end{array}$ & $\underset{\left({ }^{\circ} \mathrm{C}\right)}{\text { Temp. }}$ & $\underset{(\mathbf{h})}{\text { Time }}$ & $\begin{array}{l}\text { Concentration } \\
\text { of the solution } \\
(\%)\end{array}$ & $\begin{array}{c}\text { Temp. } \\
\left({ }^{\circ} \mathrm{C}\right)\end{array}$ & $\underset{(h)}{\operatorname{Tim} e}$ & \\
\hline SPU-2 & 1830 & 0 & 3 & 15.0 & 30 & 1.5 & 4.1 & $\begin{array}{c}30 \\
30-50\end{array}$ & $\begin{array}{l}1.5 \\
0.5\end{array}$ & 77 \\
\hline SEU-3 & 2490 & 31 & 3 & 17.6 & 30 & 1.5 & 4.9 & $\begin{array}{c}30 \\
30-50\end{array}$ & $\begin{array}{l}1.5 \\
0.5\end{array}$ & 77 \\
\hline SEU-6 & 4040 & 62 & 3 & 23.0 & 29 & 1.5 & 6.7 & $\begin{array}{c}30 \\
30-50\end{array}$ & $\begin{array}{l}1.5 \\
0.5\end{array}$ & - \\
\hline
\end{tabular}

a) By the prepolymer method.

b) Measured by VPO.

c) Measured by ${ }^{1} \mathrm{H}-\mathrm{NMR}$.

d) 1,8-Diazabicyclo[5.4.0]undecene-7 (DBU) as a catalyst.

e) Not determined. 
Table 3 Results of DSC for Segmented Poiyurethane

\begin{tabular}{ccc}
\hline Sample code & $T_{\mathrm{g}, \mathrm{s}}^{\mathrm{a})}\left({ }^{\circ} \mathrm{C}\right)$ & $T_{\mathrm{m}, \mathrm{n}}^{\mathrm{b}}\left({ }^{\circ} \mathrm{C}\right)$ \\
\hline SPU-2 & -67.0 & 260.6 \\
SEU-3 & -76.0 & 263.3 \\
SEU-6 & -79.4 & $\left.-{ }^{\mathrm{c}}\right)$ \\
\hline
\end{tabular}

- The glass transition temperature of the soft segments.

b) The melting temperature of the hard segments domain.

c) Not detected clearly.

とを示すものと考えられる．SEU-6ではハード セグメントの融点を明確に検出することはできな かった。ソフトセグメントの分子量が大きいた め，ハードセクメントのドメイン形成が充分に進 行しなかったものと推定できる，HT-ETEをブ レポリマーとするセグメント化ポリウレタンウレ フ(SEUU) と比較すると，ハードセグィントの融 点はセクメント化ポリウレタンのほうが低い值と なった。これはSEUではウレア結合に由来する 水素結合がなく，そのためめードセグィントの凝 集力が SEUUに比べて弱いことに起因するもの と考えられる。

\section{3 セグメント化ポリウレタンの抗血栓性}

Table 4 に Lee-White 法凝血試験の結果を示す. SPUに比べPEO ニニットを有するSEU のほう が GTI 值が大きく，優れた抗血栓性を有してい ることが判明した. SEUUに括いても PEOュニ ットの導入により抗血栓性は向上しており，七グ メント化ポリウレタン及びポリウレタンウレフで は同様の傾向を示すことがわかった．また，本実 験方法ではSEU と SEUU は同程度の抗血栓性を 有しているといえる.

Fig. 3 に血小板粘着試験の結果を示す．SEU 表面における血小板粘着数は SPU 表面に比べて 少なく，Lee-White 法凝血試験の結果と同様に

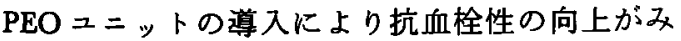
られた，抗血栓性発現の要因はンフトセグメント にEOニニットを導入したことにより親水性が増 加し，界面自由エネルギーが低下したためにタン ヘク質との相互作用が弱くなったことであると考 えられる16).

抗血栓性は血液と材料表面との相互作用により 決定される性質であるので17),18)，材料表面の組 成分析は生体適合性材料を設計する5えで極めて
Table 4 Antithrombogenicity of Segmented

Polyurethane and Polyurethaneurea

\begin{tabular}{lccc}
\hline & \multicolumn{2}{c}{ Prepolymer } & \\
\cline { 2 - 3 } Sample code & Mn $^{\text {a) }}$ & $\begin{array}{c}\text { EO content } \\
(\text { mol\%) }\end{array}$ & CTI $\left.^{\mathrm{c}}\right)$ \\
\hline SPU-2 & 1830 & 0 & 3.5 \\
SEU-3 & 2490 & 31 & 4.4 \\
SEU-6 & 4040 & 62 & 4.9 \\
SPUU-2d) & 1830 & 0 & 3.6 \\
SEUU-3 & 2430 & 33 & 4.9 \\
SEUU-6 & 4040 & 62 & 4.3 \\
\hline
\end{tabular}

a) Measured by VPO.

b) Measured by ${ }^{1} \mathrm{H}-\mathrm{NMR}$.

c) Coogulation time index by the Lee-White method.

d) Taken from the reference 12).

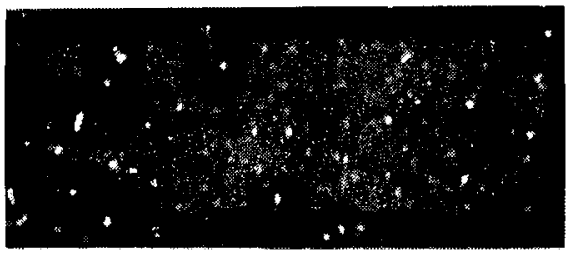

SPU-2

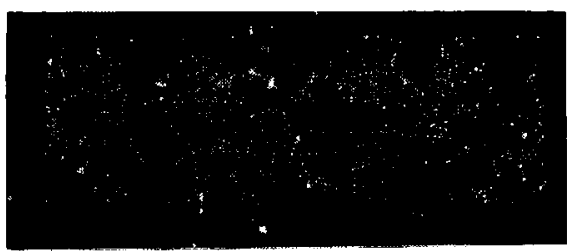

SEU-3

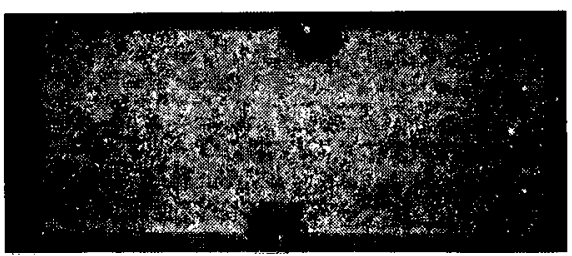

SEU-6

$10 \mu \mathrm{m}$

Fig. 3 Scanning electron micrographs of platelets adhered on the surfaces of segmented polyurethanes.

重要である ${ }^{19)}$.SEUのソフトセグメントはセン ターブロックPTHF の両末端に PEO ブロックを 有するポリェーテルであり，フィルムの表面層て はかなり複雑なモルフォロジーが形成されている 
ものと思われる. 今後, 詳細な表面分析により検 討する必要がある。

\section{4 セグメント化ポリウレタンの力学的性質}

Fig. 4 にセグメント化ポリウレタンの乾燥フィ ルムと $37^{\circ} \mathrm{C}$ 生理食塩水に 2 週間浸せきした後の 含水フィルムの引張試験における応力ーひずみ曲 線を示す。乾燥フィルム及び含水フィルムどちら においても31 mol\%のPEOニニットを導入した SEU-3 はSPU-2に比べ, 300 400\%の大変形 時の応力は小さく，人工血管などの医用材料に有 用であると思われる。しかし，SEU-3の破断時 の引張強さは乾燥状態では SPU-2 に匹敵するが 含水により的 2 分の 1 の值となり，七グメント化 ポリウレタンウレアと比較してもその値は小さい，

一般にポリウレタンは水によって加水分解を受 けやすくウレタン結合の切断による力学的性質の

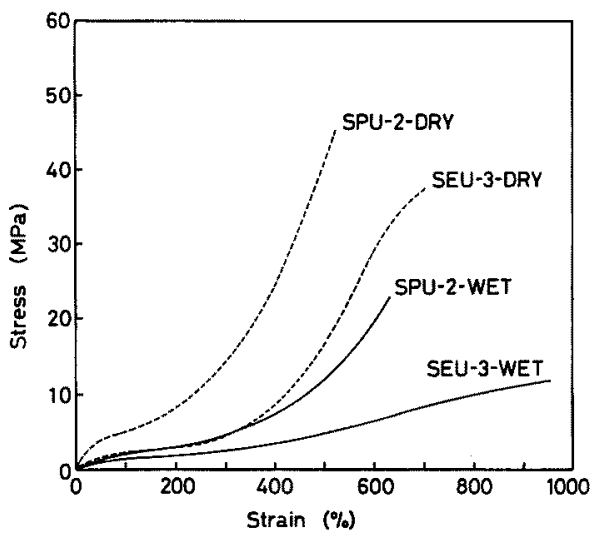

Fig. 4 Tensile stress--strain curves of segmented polyurethanes.

--- ; dry films, — $\longrightarrow$;et films.
低下が知られている20)。また，PEOをソフトセ ク゚メントとするセグメント化ポリウレタンウレア は耐加水分解性に乏しい21). Table 5 K37 ${ }^{\circ} \mathrm{C}$ 生理 食塩水に 6 か月間漫せきした後の引張特性を示す。 2 週間浸せき後の結果と比較して, SEU-3では 力学的性質の低下は認められず，良好な耐加水分 解性を示している.

コム弾性体の引張特性を記述する式として Mooney-Rivlin 式22),23)が知られている.

$$
\sigma=2\left(C_{1}+\frac{C_{2}}{\alpha}\right)\left(\alpha-\frac{1}{\alpha^{2}}\right)
$$

ここで, $\sigma:$ 引張応力, $\alpha:$ 伸長比, $C_{1}, C_{2}$ : 定数であり， $C_{1}$ は次式で表わされる.

$$
2 C_{1}=v k T
$$

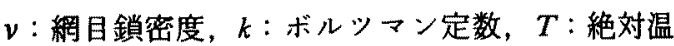

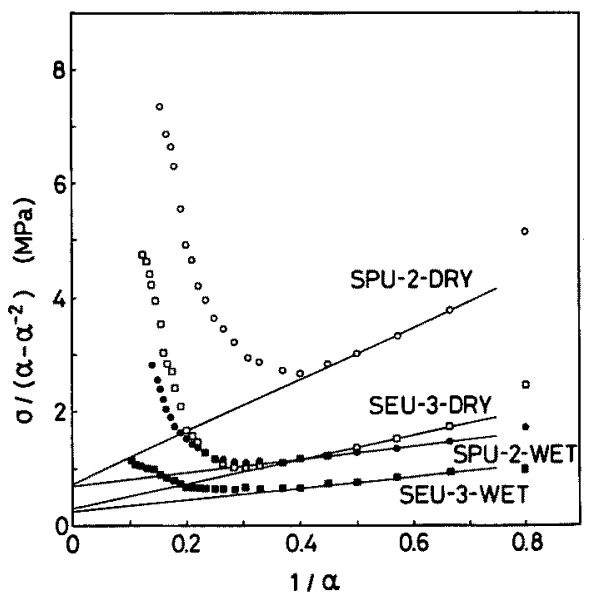

Fig. 5 The Mooney-Rivlin plots of segmented polyurethanes.

$\bigcirc, \square$; dry films, $\boldsymbol{\bullet}$, $\mathbf{\square}$; wet films.

Table 5 Hydrolitic Stability of Segmented Polyurethane $\mathrm{e}^{\mathrm{a}}$

\begin{tabular}{cccccccc}
\hline Sample code & $\begin{array}{c}\text { EO content } \\
(\mathrm{mol} \%)\end{array}$ & Soaking time & $\begin{array}{c}\text { Water content } \\
(\mathrm{wt} \%)\end{array}$ & $M_{50}^{\mathrm{b})}$ & $\left.M_{300}^{\mathrm{c}}\right)$ & $T_{\mathrm{B}}^{\mathrm{d})}$ & $\begin{array}{c}E_{\mathrm{B}}^{\mathrm{e})} \\
(\%)\end{array}$ \\
\hline \multirow{2}{*}{ SPU-2 } & \multirow{2}{*}{0} & 2 weeks & 3.7 & 1.3 & 4.6 & 21.1 & 630 \\
& & 6 months & 3.6 & 1.5 & 5.1 & 16.4 & 640 \\
SEU-3 & \multirow{2}{*}{31} & 2 weeks & 11.9 & 1.0 & 2.6 & 11.7 & 955 \\
& & 6 months & 12.3 & 0.8 & 2.7 & 12.7 & 975 \\
\hline
\end{tabular}

a) Sample films were soaked in normal saline solution at $37^{\circ} \mathrm{C}$.

b) Stress at $50 \%$ elongation.

c) Stress at $300 \%$ elongation.

d) Tensile strength at break.

e) Elongation at break. 
度である. Fig. 5 に Mooney-Rivlin プロットを， Table 6 に Mooney-Rivlin プロットの切片及び勾 配から求めた $C_{1}, C_{2}$ 及び式(3)から計算した $v$ を 示す，七グメント化ポリウレタンはソフトセグメ ントとハードセグメントがミクロに相分離した構 造を有し，ハードセグメントがウレタン基の水素 結合より凝集しているため，これが擬架橋点とな り，高い弾性率を有している，乾燥試料と含水試 料を比較すると， $C_{1}$ はほ注同じ值となり， $C_{2}$ は 含水により低下した。また，PEOセグメントの 導入により $C_{1}, C_{2}$ はともに減少した， $C_{2}$ につい ての傾向はPEO-PTHF-PEOをンフトセグメン トとするセグメント化ポリウレタンウレアの場 合13) と一致した． $C_{2}$ 頃の意味についてはまだ明 確でない点がかなりあるが，C， より変化すること，膨潤により値は小さくなるこ と，網目鎖濃度だけでなく網目構造にも関係する ことが知られている24)。 また水酸基末端 PEOーポ り(プロピレンオキシド)-PEOをプレポりマーと してMDI，EDより合成されたセグィント化ポ リウレタンウレアでは， $C_{2}$ はミクロ相分離構造 に影響されると考えられている25). 本実験の結果 をFig. 6 に示すようにSEUUの結果と合わせて 考えると，EO 含量の増加に伴って極性が上るに つれ，また，ポリマー間の水素結合の密度が減少 寸るにつれて $C_{2}$ は低下しているといえる。この 場合，擬架橋点となるハードセグメントドメイン の影響だけではなくてンフトセグメントとハード セグメントの間の相互作用も関与しているものと 思和る。。

\section{5 セグメント化ポリウレタンの応力緩和挙 動}

Fig. 7 にセグメント化ポリウレタンの応力緩和 曲線を示す．経時的な応力値は伸長直後に発生す

Table 6 Results of Mooney-Rivlin Plot of Segmented Polyurethane

\begin{tabular}{lccc}
\hline Sample code & $\begin{array}{c}\left.C_{1}^{\mathrm{a}}\right) \\
(\mathrm{MPa})\end{array}$ & $\begin{array}{c}\left.\mathrm{C}_{2}^{\mathrm{a}}\right) \\
(\mathrm{MPa})\end{array}$ & $\begin{array}{c}\boldsymbol{\nu}^{\mathrm{b})} \\
\left(\times 10^{-4} \mathrm{~mol} / \mathrm{cm}^{3}\right)\end{array}$ \\
\hline SPU-2-DRY & 0.36 & 2.3 & 2.8 \\
SPU-2-WET & 0.34 & 0.5 & 2.7 \\
SEU-3-DRY & 0.15 & 1.2 & 1.2 \\
SEU-3-WET & 0.13 & 0.5 & 1.1 \\
\hline
\end{tabular}

\footnotetext{
a) $\sigma=2\left(C_{1}+C_{2} / \alpha\right)\left(\alpha-1 / \alpha_{2}\right)$.
}

b) $2 C_{1}=v k T$.

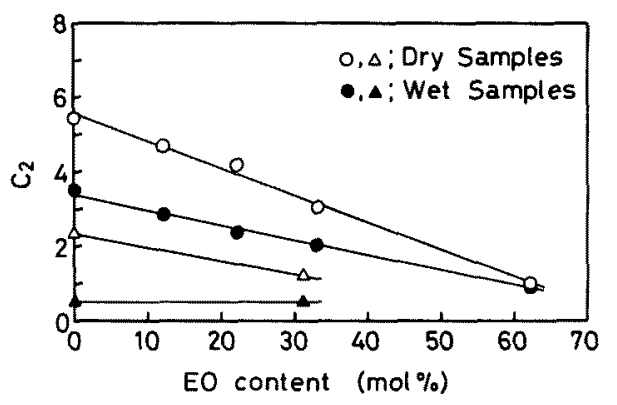

Fig. 6 Relationship between $\mathrm{C}_{2}$ and EO content.

$\bigcirc$, segmented polyurethane.

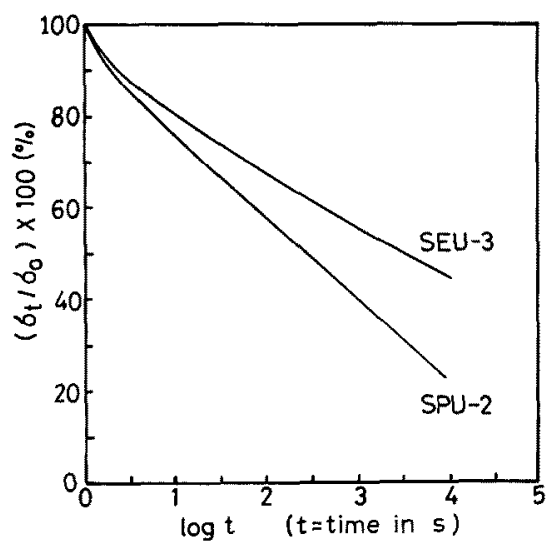

Fig. 7 Stress relaxation curves of segmented polyurethanes in normal saline solution at $37^{\circ} \mathrm{C}$.

る最大応力で規格化してある．本実験で観測され る応力の低下は化学結合上り弱い2 次結合による Networks の变形に基づく物理楥和であり ${ }^{26)}$ ，次 の経験式で表わすことができる。

$$
\frac{\sigma_{t}}{\sigma_{0}}=a-b \log t
$$

$t:$ 測定時間(秒), $a, b:$ 定数

$\sigma_{t}: t$ 秒後における庆力, $\sigma_{0}:$ 最大応力

Table 7 b Value ${ }^{\text {a) }}$

\begin{tabular}{ll}
\hline Sample code & $\mathrm{b}$ \\
\hline SPU-2 & 0.54 \\
SEU-3 & 0.32 \\
SPUU-2 & 0.57 \\
SEUU-3 & 0.15 \\
\hline
\end{tabular}

a) $\sigma_{i} / \sigma_{0}=\mathrm{a}-\mathrm{b} \log t$.

b) Taken from the reference 13 ). 
ポリマーのb 值を Table 7 に示す。セグィント 化ポリウレタンの $b$ 值はセグメント化ポリウレタ ンウレアの場合と同様に PEO 含量の増加に伴う 分子鎖長の增加に従って小さくなり，応力楥和は 減少した。しかし，水素結合がポリウレタンウレ アより弱いため相対的に值は大きい。これらの違 いはミクロ相分離構造の発達の程度により支配さ れているのであるう。

\section{4. 結語}

PEO-PTHF-PEOトリプロックコポリエーテ ルより合成したセグメント化ポリウレタン (SEU)はPTHFをンフトセグメントとするセグ メント化ポリウレタン (SPU) と比較して，親水性 のポリ(オキシェチレン)単位の導入により優れた 抗血栓性を示した。学的性質については，EO 含量 $31 \mathrm{~mol} \%$ の SEUはSPU と比較して含水状態 での破断時の強さは低いが大变形時における応力 や応力緩和が小さく，耐加水分解性も良好で人工 血管などの医用高分子材料として非常に有用であ ると考学られる. 今後更に，耐久性を中心に生体 内劣化の評価27)を行う必要がある。

(本研究の一部は日本ゴム協会第55回通常総会研 究発表講演会(昭和63年 5 月)において発表した。)

\section{引用 文 献}

1）日本化学会編：医用枋料の化学，化学総説，No. 21 , 学会出版センタ一，東京（1978）

2) 日本材料化学会編：材料学の最近の進歩，オーム 社, 東京 $(1982)$ p. 108

3) Pieece, W. S., Turner, M. C., Boretos, J. W., Metz, H. D., Nolan, S. P., Morrow, A. G.: Trans. Amer. Soc. Artif. Int. Organs, 13, 299 (1967)

4) Ihlenfeld, J. V., Mathis, T. R., Riddle, L. M., Cooper, S. L.: Thromb. Res., 14, 953 (1979)

5) Lelah, D., Lambrecht, L. K., Young, B. R., Cooper, S. L.: J. Biomed. Mater. Res., 17, 1 (1983)

6) Borelos, J. W., Pierce, W. S., Baier, R. E., Eeroy,
A. F., Donachy, H. J.: J. Biomed. Mater. Res., 9, 327 (1975)

7) Borelos, J. W.: Pure Appl. Chem., 52, 1851 (1980)

8) Lawson, J. H., Fukumasu, J., Olsen, D. B., Jervik, R. K., Kessler, R. T., Coleman, D. L.: J. Thorac, Cardiovasc, Surg., 78, 150 (1979)

9) Szycher, M., Poirier., V. L., Dempsey, D.: Elastomerics, No. 3, 11 (1983)

10) ITO, Y.: Biomaterials Applications, 2, 235 (1987)

11) Han, D. K., Jeong, S. Y., Kim, Y. H., Ahn, K-D., Kim, U. Y.: Preprints of IUPAC 32nd International Symposium on Macromolecules 1988 , Kyoto, p. 590

12）池田裕子，粅谷信三，山下晋三，山本晴，林 和子，山下岩男：日化誌，1986，699

13）粷谷信三, 池田裕子, 山下晋三, 林 和子, 山本 襄，山下岩男：日ゴム協誌，59，685（1986）

14）今井康二：第15回医用高分子研究会講演要旨集, 29 (1982)

15）長谷川正光, 渡辺嘉雄 : 日本レオロジー学会誌, 13, 178 (1985)

16) Matuda, T., Akutsu, T.: ACS Preprints (Polymer Materials Science and Technology), 48, 498 (1983)

17) Andrade, J. D., Coleman, D. L., Didsheim, P., Hanson, S. R., Merrill, E.: Trans. Am. Soc. Artif. Int. Organs, 27, 659 (1981)

18) Leeper, H. M., Wright, R. M.: Rubber Chem. Tech., 56, $540(1983)$

19）松田武久：Polym. Preprints, Japan, 37, 29 (1988)

20）黑田栄美：第18回日本ゴム協会技術シンポシウム テキスト, 60 (1984)

21) Stenzenberger, H.-D., Hummel, D. O.: Angew. Makromol., 82, 103 (1979)

22) Mooney, M.: J. Appl. Phys., 11, 582 (1940)

23) Rivlin, R. S.: "Rheology, vol. I", Academic Press, N. Y. (1986)

24）岡本 弘：日ゴム協誌，48，623（1975）

25）山下岩男, 山本 襄, 林和子：日ゴム協誌, 61, 579 (1988)

26）渡辺健二：日ゴム協誌，33，882（1960）

27）鶴田禎二, 桜井靖久編：バイオマテリアルサイェ ンス第 1 集, 化学の領域, 堌刊134号, 南江堂, 東 京 (1982) p. 183

\title{
ANTITHROMBOGENICITY AND MECHANICAL PROPERTIES OF SEGMENTED POLYURETHANE BASED ON PEO-PTHF-PEO TRIBLOCK COPOLYETHER
}

\author{
Yuko IKEDA, Shoichi TAKESAKO, Shinzo KOHJIYA, Shinzo YAMASHITA (Depart- \\ ment of Industrial Chemistry, Faculty of Engineering and Design, Kyoto Institute of \\ Technology, Matsugasaki, Sakyo, Kyoto 606), and Iwao YAMASHITA (Government \\ Industrial Research Institute, Osaka, Midorigaoka, Ikeda, Osaka 563)
}


Segmented polyurethane (SEU) was synthesized from hydroxylterminated poly (oxyethylene)-poly (oxytetramethylene)-poly (oxyethylene) triblock copolyether, 4, 4'diphenylmethane diisocyanate and ethylene glycol by the prepolymer method. Antithrombogenicity of SEU evaluated by the Lee-White coagulation test and by the platelet adhesion test was found to be better than that of segmented polyurethane based on poly (oxytetramethylene) (SPU). The SEU also exhibited low modulus at elongation of 300-400\% and a good hydrolytic stability up to six months. The value of $\mathrm{C}_{2}$ derived from the MooneyRivlin Plot of stress-strain curve was found to decrease with the increase of oxyethylene (EO) content in the prepolymer. The stress relaxation measurement in normal saline solution at $37^{\circ} \mathrm{C}$ revealed that the stress relaxation of SEU was smaller than that of SPU. These findings were interpreted in terms of the better microphase separation and of the more hydrophilic nature of SEU than those of SPU owing to the introduction of poly (EO) units in the prepolymer.

(Received September 2, 1988)

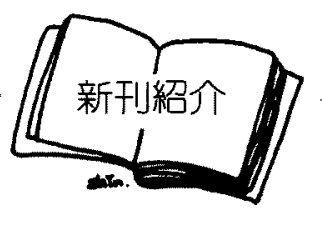

Rubbery Materials and their Compounds ゴム材料と複合物

\section{J. A. Brydson}

(Formerly Head, Depertment of Physical Sciences and Technology, Polytechnic of North London, UK.)

$$
£ 68.00 \text { (概価 } ¥ 24,480 \text { ) } 458 \text { ページ }
$$

歴史的経過と構造一性質相関の基礎，各種材料の種別各論，主要添加物各論，複合化の調合 技術で構成されている. 付編で添加物の比重，ムーニー粘度計，一般文献，加硫ゴムの分類を 示し，最近のゴム材料技術を応用面を重視して解説しており，価値ある技術参考書として注目 される.

問合せは，エルゼビア・サイェンス・パブリッシャーズ日本支社（テ113 東京都文京区湯島 3-28-1, $203-836-0810$ ) 